\title{
Urban dimensions for neighborhoods with higher environmental value
}

\author{
K. Conde \& S. Pina \\ Graduate Program in Architecture, Technology and the City, \\ University of Campinas, UNICAMP, Brazil
}

\begin{abstract}
The quality of the urban residential environment is closely related to the quality of life, and how people perceive their surroundings. From observations some neighbourhoods make concerning the use of their urban spaces over the years, the authors hypothesize that a set of urban elements could provide and maintain urban environmental quality, whose value added is perceived by the community assessing their urban dimensions. The objective of this research is to identify the urban dimensions to which higher environmental value is attributed. This paper presents the results of an exploratory study with the development of a case study, in which a neighbourhood in the city of Vitoria ES, Brazil, is assessed. Designed in 1952, the layout of the neighbourhood remained basically unchanged, and despite the population growth and changes in the urban landscape, such urban spaces have preserved their use throughout decades. Sources of documentary evidence and interviews with residents are used to characterize the residential district. Applying the Stated Preference Method, using 24 picture cards representing value attributes of urban design in socio-cultural, environmental, economic, and human interaction contexts at city and neighbourhood levels the perceived environmental value was assessed. Safety is the most desired attribute for the residents interviewed, followed by: mobility, diversity of shops and services. Except for safety, all the other attributes are perceived as value added in the neighbourhood where they live. Thus, the neighbourhood studied is considered a full housing territory bringing value to the residents and significantly contributing to the quality of urban life.

Keywords: urban environmental value, urban design, quality of the urban life, urban environment perception.
\end{abstract}




\section{Introduction}

Urban environmental quality is influenced by a wide array of aspects that comprise its physical-environmental dimensions and systems of activities interacting with the population by means of the way the community utilizes, perceives, and leads their daily life [1]. Hence it is related to the humanization of urban areas, which will be interpreted as on how the city is experienced in urban areas that prioritize human scale and on how the areas are kept attractive to community life [2].

Urban dimensions consist of the set of urban elements and the relationship built with its association with multidimensional aspects of the value added by who utilizes or resides at a given place [3]. Certain urban areas are identified as of high environmental quality due to the vitality of their urban spaces kept over the years. They constitute full residential areas when they add value to the residents and strengthen their citizenship [4].

Bearing in mind that urban landscape provides residents with a perception of environmental value, which in turn contributes to its quality enhancement, this paper has the objective of identifying urban dimensions in key aspects concerning morphology, perception, and urban design, as well as the components incentivizing the maintenance of the vitality in a given residential area. To achieve such objective, an exploratory study was carried out with the development of a case study in Jardim da Penha neighborhood, in Vitoria, Espirito Santo State, Brazil, for the area shows an urban plan that characterizes and provides support for the community life and utilization over the decades.

The roles that urban morphology and design play in the formation of the urban landscape and in the quality of urban open areas are investigated in the light of the perception of urban environment by the residents, thus characterizing Jardim da Penha neighborhood. Also, the attributes of the urban environmental value perceived by the community are both identified and hierarchically organized. Investigation techniques of environmental perception applied in case studies are utilized to subsidize recommendations of urban design, so as to add higher urban environmental value to the residential territories $[5,6]$.

\section{Research background}

The first level of perception of the city is physical-spatial and morphological, once it allows for evidencing the difference between the areas and aids the understanding of the features of every part of the city. There are other levels of perception and their various historical, economic, social, and cultural contents. Likewise, urban design is inextricably linked to behavior, ownership, and use of space as well as community life of citizens, and it is exactly in the details and particularities of the morphology and urban design where human relationships happen $[2,7,8]$.

The Commission for Architecture and the Built Environment considers a set of objectives that attribute quality to urban environment, and they are listed below. The objectives interrelate, influence, and enhance one another [9]: 
- Character and identity: they promote and strengthen local patterns of development and culture. It is linked to a sense of belonging. The sense of belonging and responsibility for the area transcends local maintenance and management, because it builds up in the community responsibility and commitment to the space;

- Continuity and definition of limits: they clearly define public and private areas. Also defined as privacy;

- Accessibility and permeability: to make public spaces and routes attractive, safe, and organized to everyone in the society, including the disabled and the elderly. Permeability is one of the concepts responsible for the use of the built environment, and is represented by the ability that an urban area has to offer people choices of paths to other parts of the neighborhood or the city;

- Mobility: it promotes accessibility and local permeability, creating places that connect with each other through easy routes, prioritizing people to traffic, integration and means of transportation;

- Legibility: promote legibility through recognizable paths, intersections and visual landmarks. The organization of the built environment can help alleviate feelings of fear and enhance the sense of tranquility;

- Adaptability and flexibility: it promotes development that can respond to the changes in the social, technological and economic conditions and;

- Diversity: promoting diversity and choice through a mix of uses and development so as to create places that meet local needs.

Thus, urban design is defined as a science whose role is to deal with urban space in its public dimension of living space of the community's everyday life, according to which, experience and quality of life stand as priorities. Therefore, urban design and the relationships built associating the value aspects of who uses a particular place can be a tool to promote and incentivize places with greater urban environmental quality, fostering the use of urban spaces and quality of urban life [10].

Quality of life is directly related to how the individuals perceive the environment they live in, because it represents something more than a socioeconomic level and covers all needs and satisfactions of an individual. Hence studying the quality of life of a community is not only to assess the physical conditions of the environment, but also the social and subjective experiences individuals have of their existence in their residential territory [11]. Levi and Anderson [12] consider that above the minimum standard of living, which includes the basic physiological needs, the key factor to the quality of life of an individual is the adjustment and matching, i.e. the relationship between the characteristics of the situation and expectations, such as how the individual perceives them.

The value of urban space is determined by the context and the relationship the users have with this space, with the benefits and sacrifices they perceive when enjoying such space, in the light of their own values. In other words, value is the ratio between the benefits, or what is received and the sacrifices, which can be interpreted as what you give up on. Values are the criteria for judging the value, 
subjective to each individual, based on cultural standards, but are also formed in societies from common points of view [13].

The values, constituted by human needs, influence the spaces and the daily lives of people, making urban design a generating element of social, cultural, environmental and economic values. For this reason, it is considered important to find ways to quantify the value, considering attributes or preferences in the relationship of man with his environment built from the individual's own views $[3,14-16]$. Once identified what people value most, new places and interventions in the environment may meet the real needs of the community, contributing to higher urban environmental quality. Similarly, a specific urban element can target a certain aspect or behavior involving a particular value attribute, as illustrated and exemplified in Figure 1. The interaction of the various elements of urban design and the ability to influence and reinforce one another is emphasized to enhance environmental quality [17-19].
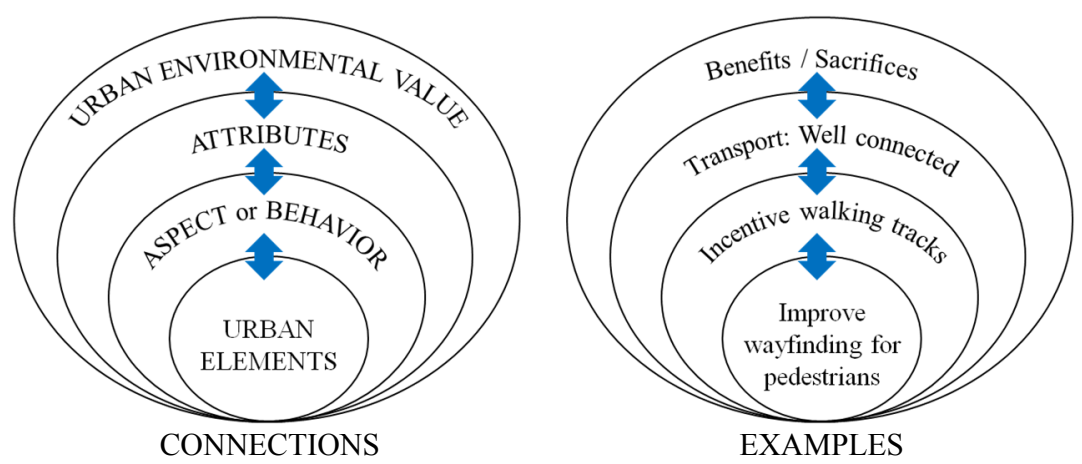

Figure 1: Interrelationship among urban elements and perceptions of urban environmental value.

\section{Research method}

Investigative techniques of environmental perception applied in case study were used to identify: the elements that characterize urban landscape; the use and perception of residents in relation to open spaces available, and the attributes of urban environmental value perceived by the residents, so as to identify the set of elements to which higher environmental value is attributed in the urban residential district under study. Figure 2 illustrates the diagram for analysis of results.

Documentary sources and interviews were the basis to characterize urban space and its use by its residents. Press records in articles published in the main local newspapers made possible to diagnose the changes in the urban landscape over the years. At the level of field research, with interviews and mind maps application, the authors tried to reveal aspects of the two levels of perceptive process of the respondents: the image formation, and the assessment and behavior [20]. 


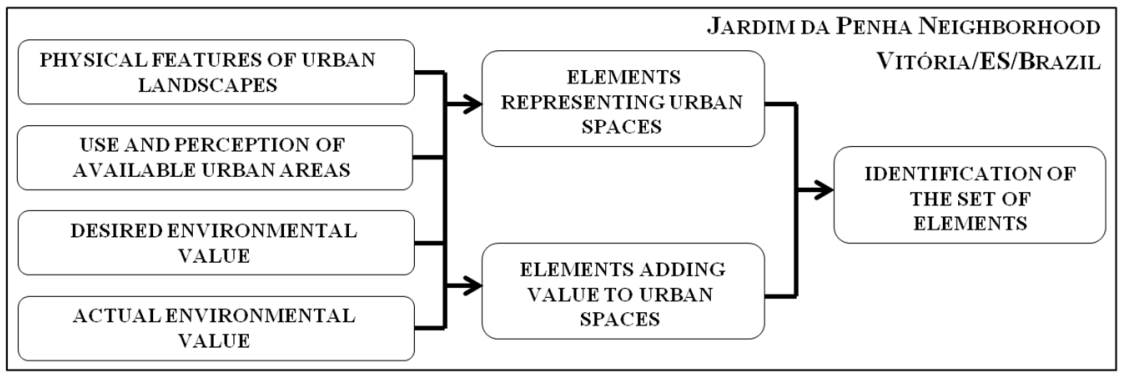

Figure 2: Diagram for analysis of results.

The indirect method of mind mapping was used, i.e. the respondents were asked to name the first five physical elements they could remember, or feelings related to their experience in the neighborhood. It was observed what the respondents first mentioned, which revealed their cognitive intensity. They were also asked to describe the most used routes and means of transportation to move across the neighborhood. For each respondent, a map was used to register their responses [20].

The hierarchical organization of the desired environmental value attributes aims at identifying the profile of the residents as its definition of what is to be an ideal neighborhood to live in. For such, the Stated Preference Method was applied, which consists basically in presenting several alternatives to the respondents so that a choice could be used. The choice of the respondent indicates his preferred choice of attributes in relation to other alternatives [14, 21, 22].

For the application of the Stated Preference Method, illustrated cards were used developed by De Paoli [3] in a methodology designed to assess the perception of value in residential neighborhoods. The set of cards features five categories of urban environmental value, namely: environmental, socio-cultural, economic, human interactions at city and at neighborhood contexts. Each category of value includes value attribute for a total of 24 cards. Each card has clearly and concisely written the attribute and an illustration referring to each meaning. Table 1 presents the list of categories of value and value attributes related to each category with their respective objectives of urban design.

The Stated Preference Method was applied, as follows: the first cycle, with 5 rounds, one for each category, so that the interviewees hierarchically organize among their preferences of attributes that make up each category; the second cycle was led in order to select only the first choices in each category, so this way, in the second cycle, the respondents will rank the most important 5 choices in each category chosen in the first round. Scores are given to the data obtained, so as to reveal the hierarchy of value attributes of the respondents. 
Table 1: $\quad$ Set of 5 value categories and 24 value attributes and their respective objectives in urban design.

\begin{tabular}{|c|c|c|}
\hline $\begin{array}{c}\text { VALUE } \\
\text { CATEGORIES }\end{array}$ & OBJECTIVES & $\begin{array}{c}\text { VALUE ATTRIBUTES } \\
\text { (cards) }\end{array}$ \\
\hline \multirow{5}{*}{$\begin{array}{c}\text { ENVIRONMENTAL } \\
\text { VALUE }\end{array}$} & Energy efficiency/accessibility & Pollution-free environment \\
\hline & Accessibility/legibility/identity & Sense of place \\
\hline & Belonging & $\begin{array}{l}\text { Participation in local } \\
\text { community }\end{array}$ \\
\hline & Identity/belonging & Green areas and gardens \\
\hline & Energy efficiency/flexibility & $\begin{array}{l}\text { Preserving, recycling and } \\
\text { re-utilization }\end{array}$ \\
\hline \multirow{5}{*}{$\begin{array}{l}\text { SOCIO-CULTURAL } \\
\text { VALUE }\end{array}$} & Identity/belonging & Urban equipment \\
\hline & Identity/belonging & $\begin{array}{l}\text { Using the existing } \\
\text { premises }\end{array}$ \\
\hline & $\begin{array}{c}\text { Accessibility/belonging/ } \\
\text { flexibility }\end{array}$ & Inclusion \\
\hline & $\begin{array}{l}\text { Accessibility/legibility/identity/ } \\
\text { belonging }\end{array}$ & Sense of tranquility \\
\hline & Accessibility/vivacity & Safety \\
\hline \multirow{5}{*}{ ECONOMIC VALUE } & Identity/flexibility/belonging & $\begin{array}{c}\text { Property value } \\
\text { increase/easy trading }\end{array}$ \\
\hline & Identity/belonging & $\begin{array}{l}\text { Neighborhood enhances } \\
\text { the image of the city }\end{array}$ \\
\hline & Diversity/vivacity & $\begin{array}{c}\text { Variety of commerce and } \\
\text { service }\end{array}$ \\
\hline & Energy efficiency/accessibility & $\begin{array}{c}\text { Saving and increasing } \\
\text { value } \\
\end{array}$ \\
\hline & Energy efficiency & Easy-care environment \\
\hline \multirow{4}{*}{$\begin{array}{c}\text { HUMAN } \\
\text { INTERACTIONS AT } \\
\text { CITY CONTEXT }\end{array}$} & Accessibility/energy efficiency & City access \\
\hline & Permeability & Neighborhood connection \\
\hline & Diversity/vivacity & $\begin{array}{c}\text { Houses, commerce and } \\
\text { services of different types }\end{array}$ \\
\hline & Legibility & Mobility and legibility \\
\hline \multirow{5}{*}{$\begin{array}{c}\text { HUMAN } \\
\text { INTERACTIONS AT } \\
\text { NEIGHBORHOOD } \\
\text { CONTEXT }\end{array}$} & Permeability/mobility & $\begin{array}{c}\text { Variety of available } \\
\text { transport }\end{array}$ \\
\hline & $\begin{array}{l}\text { Flexibility/diversity/energy } \\
\text { efficiency }\end{array}$ & $\begin{array}{c}\text { Variety of people and } \\
\text { activities }\end{array}$ \\
\hline & Vivacity/activity & Leisure and meeting spots \\
\hline & Accessibility & $\begin{array}{c}\text { Link between house and } \\
\text { road }\end{array}$ \\
\hline & Privacy/belonging & Privacy \\
\hline
\end{tabular}


The perception of the actual environmental value aims at identifying the value assessment concerning living in a certain neighborhood. For such, the residents were questioned whether or not they perceive as actual value in the neighborhood under study the first attribute (card) selected by them as the most important one in the five value categories.

The residents participating in the case study were randomly selected, so that their place of residence would be equally distributed. This paper presents preliminary results of the $\mathrm{PhD}$ research. The sample consists of 10 residents of the Jardim da Penha neighborhood in Vitoria, ES, Brazil, and will be further expanded throughout this research. An average of 40 minutes per respondent was used.

In order to identify the elements or set of urban elements that place more environmental value in the residential area under study, the attributes of higher environmental value perceived by residents and the relationship of these attributes with urban elements present in the district are identified.

\section{Results}

The proposed urban plan of Jardim da Penha neighborhood dates back to 1952, by Creso Euclydes, Engineer graduated in International Schools of Scranton, Pennsylvania, USA (1945) and Technical Director of the Institute of Guidance for Housing Cooperatives ES, Brazil (1967).

The layout of the neighborhood consists of an orthogonal network of wide avenues, diagonally meeting together to form squares of $80 \mathrm{~m}$ of diameter, juxtaposing with another layout formed by streets, both parallel to one another and perpendicular to the shore. The sketch refers to a merger of French urban traditions of the eighteenth century with the American urban tradition, as for example: the square as a place of roads intersection and avenues with long vanishing points in perspective with reticular matrix planning. Figure 3 shows the limits and layout of Jardim da Penha neighborhood.

The buildings occupy almost all the area of the lot, leaving no room for leisure facilities, so residents use the public open spaces for recreation and interaction with the neighborhood. With medium-sized blocks of $55 \mathrm{~m}$ by $200 \mathrm{~m}$, cut by diagonal pathways, Jardim da Penha promotes a wide range of connections and possible route for walkers. On the other hand, the layout and uniformity of building typologies emphasize some difficulty for visitors in what wayfinding and signage are concerned, requiring familiarity with the neighborhood to move around. Four large squares function as reference, known by their identities and uses, rather than their names (Figure 4) [23]. 


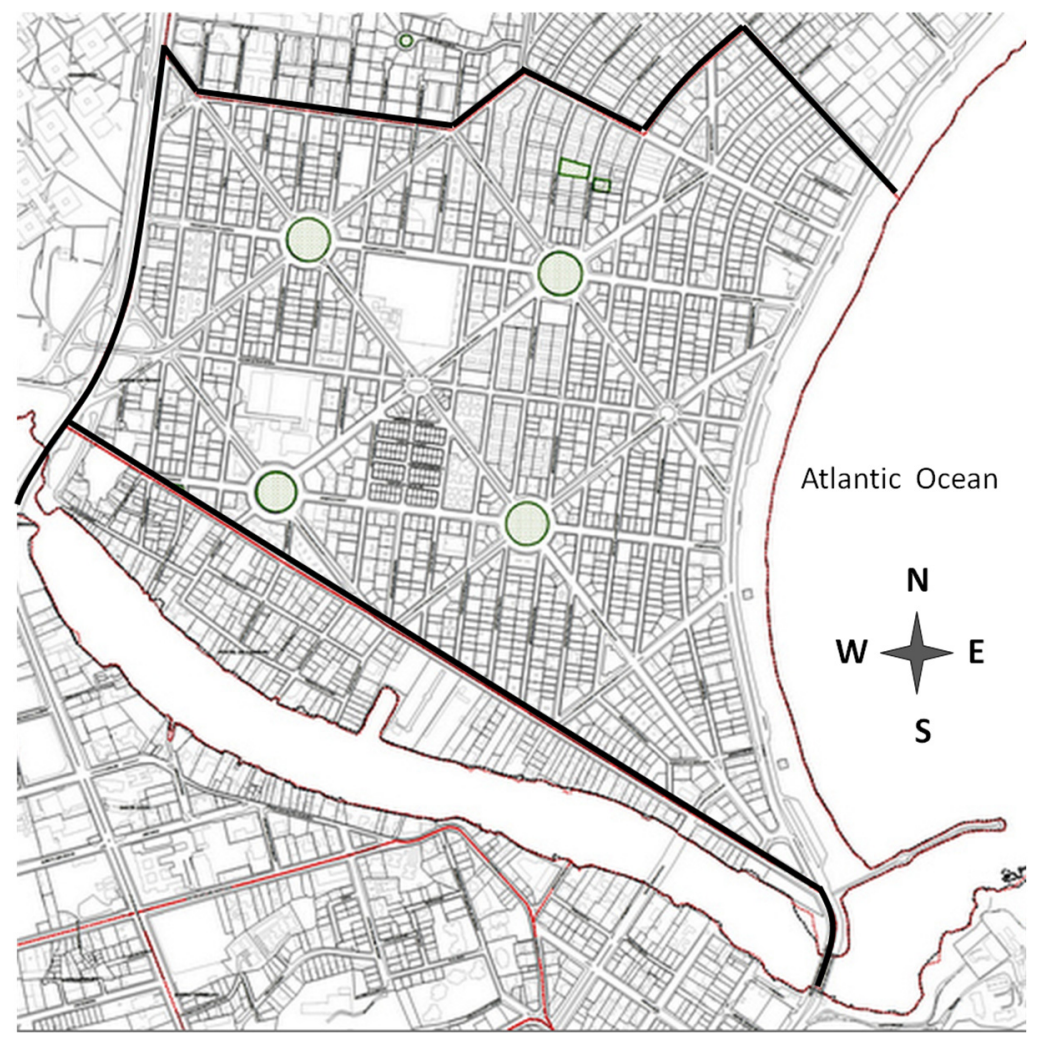

Figure 3: Limits and layout of Jardim da Penha in Vitoria, ES, Brazil.

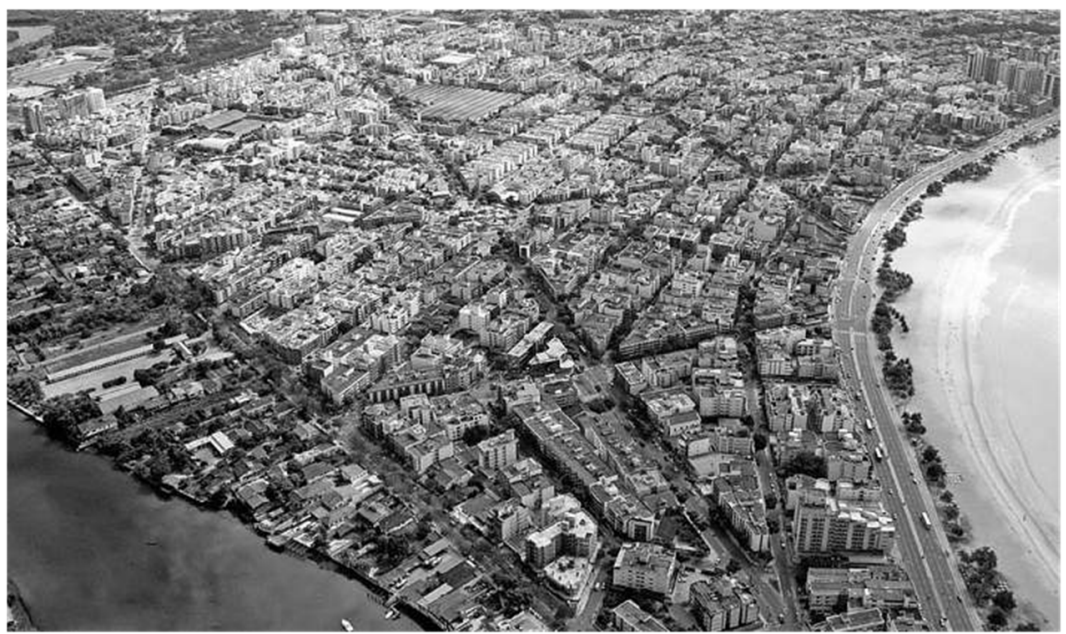

Figure 4: Overview of Jardim da Penha neighborhood. 
The neighborhood is mostly residential, and also well-served with commerce and services, mostly located on the streets diagonal and perpendicular to the shore, in mixed-use buildings that follow the same typology of the neighborhood, with the ground floor used for commerce and services and other floors for business rooms or residential apartments. The layout of the neighborhood and the variety of services, shops and facilities the neighborhood offers encourages walking, thus contributing to the vivacity of urban spaces. The promenade is equipped with gardens, sports facilities, sidewalks, bike lanes, parking lots, and public transport. It attracts residents for sports and leisure coming from different neighborhoods in the city of Vitoria.

Jardim da Penha neighborhood is identified by the residents interviewed as a place of easy mobility, although the urban layout was initially difficult, as a rule, taking residents five months or more to locate themselves in the neighborhood. Respondents were unanimous when asked about the places they use in the neighborhood, namely: the promenade, the flea market open on Saturdays, and the two large squares near the beach.

Large squares distribute the traffic and keep the flow of vehicles with low speed. The streets parallel to the shore are narrow and one-way, which often makes it difficult to drive to and access certain parts of the area. As the streets are narrow and the buildings are far too close to one another, the interviewees claim lack of privacy.

Journalistic reports show an active community always seeking for improvements in infrastructure and social life. Respect to the pedestrian was considered an element that differentiates Jardim da Penha from other neighborhoods.

Table 2 shows the five value attributes most desired by residents and the urban elements in Jardim da Penha, so as to contribute or not to the perceived actual value.

\section{Conclusions}

The urban dimension at morphological, urban design, and perceptive levels, and relationships built associating the value aspects of who uses a certain place may be a tool to promote and encourage areas with greater urban environmental quality, promoting vivacity of urban spaces and better quality of life for their users. Once identified what people value most, new places and interventions in the environment shall meet the real needs of the community. For such, research techniques in environmental perception applied in case study are addressed to subsidize recommendations of urban design of contextualized nature, so as to contribute to residential areas with higher urban environmental value, as well as to provide support to public policies.

In the residential area under study, the diversity of commerce and services and the layout of streets encourages walking routes and attribute vivacity to public spaces. However, safety, the most desired value attribute, was not perceived as an actual value in the neighborhood, which underlines the importance of developing a suitable system of local management, to improve conditions for maintenance and lighting of public spaces, associated with a community policing program. 
Table 2: Value attributes and urban elements - Jardim da Penha neighborhood, ES, Brazil.

\begin{tabular}{|c|c|c|c|c|}
\hline \multicolumn{2}{|c|}{$\begin{array}{c}\text { DESIRED VALUE } \\
\text { ATTRIBUTE } \\
\end{array}$} & $\begin{array}{l}\text { ACTUAL } \\
\text { VALUE }\end{array}$ & $\begin{array}{c}\text { URBAN DESIGN } \\
\text { OBJECTIVES } \\
\end{array}$ & $\begin{array}{c}\text { VALUE } \\
\text { CATEGORIES } \\
\end{array}$ \\
\hline \multicolumn{2}{|c|}{ SAFET } & $\begin{array}{c}\text { NOT } \\
\text { PERCEIVED }\end{array}$ & $\begin{array}{l}\text { ACCESSIBILITY } \\
\text { VIVACITY }\end{array}$ & $\begin{array}{l}\text { SOCIO- } \\
\text { CULTURAL } \\
\text { VALUE } \\
\end{array}$ \\
\hline $\begin{array}{l}\text { URBAN } \\
\text { ELEMENTS }\end{array}$ & \multicolumn{4}{|c|}{$\begin{array}{l}\text { - Streets poorly lit at night, insufficient public lighting and/or } \\
\text { position of public lights above tree tops; } \\
\text { - Narrow streets and long blocks, approximately } 200 \mathrm{~m} \text {, making } \\
\text { the change of route more difficult, when there is sense of } \\
\text { danger. }\end{array}$} \\
\hline \multicolumn{2}{|c|}{$\begin{array}{c}\text { VARIETY OF } \\
\text { COMMERCE AND } \\
\text { SERVICE } \\
\end{array}$} & PERC & $\begin{array}{l}\text { DIVERSITY } \\
\text { VIVACITY }\end{array}$ & $\begin{array}{l}\text { ECONOMIC } \\
\text { VALUE }\end{array}$ \\
\hline $\begin{array}{l}\text { URBAN } \\
\text { ELEMENTS }\end{array}$ & \multicolumn{4}{|c|}{$\begin{array}{l}\text { - Wide array of commerce, services and facilities; } \\
\text { - Spots of common interest, less than } 500 \mathrm{~m} \text { of distance. }\end{array}$} \\
\hline \multicolumn{2}{|c|}{$\begin{array}{l}\text { MOBILITY AND } \\
\text { LEGIBILITY }\end{array}$} & PERC & $\begin{array}{l}\text { LEGIBILITY } \\
\text { ACCESSIBILITY }\end{array}$ & $\begin{array}{c}\text { HUMAN } \\
\text { INTERACTIONS } \\
\text { AT CITY } \\
\text { CONTEXT } \\
\end{array}$ \\
\hline $\begin{array}{l}\text { URBAN } \\
\text { ELEMENTS }\end{array}$ & \multicolumn{4}{|c|}{$\begin{array}{l}\text { - Street layout of difficult understanding; but pleasant to } \\
\text { residents after they understand it. Room for better signage. } \\
\text { Diagonal avenues shorten distances; } \\
\text { - Spots of common interest, less than } 500 \mathrm{~m} \text { of distance; } \\
\text { - Criticism to uneven sidewalks; } \\
\text { - Visual references, such as squares, buildings (e.g. markets), } \\
\text { shopping arcades; } \\
\text { - Street layouts and pedestrian crossing above street levels } \\
\text { reduce speed of vehicles. }\end{array}$} \\
\hline \multicolumn{2}{|c|}{$\begin{array}{l}\text { POLLUTION-FREE } \\
\text { ENVIRONMENT }\end{array}$} & $\begin{array}{l}\text { PARTIALLY } \\
\text { PERCEIVED }\end{array}$ & ACCESSIBILITY & $\begin{array}{l}\text { ENVIRONMENTAL } \\
\text { VALUE } \\
\end{array}$ \\
\hline $\begin{array}{l}\text { URBAN } \\
\text { ELEMENTS }\end{array}$ & \multicolumn{4}{|c|}{$\begin{array}{l}\text { - Street layout allowing change of route; } \\
\text { - Criticism to lack of bicycle lanes; } \\
\text { - Criticism to noise pollution, buildings too close to each other } \\
\text { and to streets. }\end{array}$} \\
\hline \multicolumn{2}{|c|}{$\begin{array}{l}\text { GREEN AREAS AND } \\
\text { GARDENS } \\
\end{array}$} & PERCEIVED & $\begin{array}{l}\text { IDENTITY/BELO } \\
\text { NGING } \\
\end{array}$ & $\begin{array}{c}\text { ENVIRONMENTAL } \\
\text { VALUE } \\
\end{array}$ \\
\hline $\begin{array}{l}\text { URBAN } \\
\text { ELEMENTS }\end{array}$ & \multicolumn{4}{|c|}{$\begin{array}{l}\text { - Green areas and gardens (squares and promenade) with urban } \\
\text { facilities to raise interest of the communities; } \\
\text { - Open spaces that meet the needs of residents of various ages; } \\
\text { clean, well-equipped and properly being taken care of. }\end{array}$} \\
\hline
\end{tabular}




\section{References}

[1] Del Rio, V. \& Siembieda, W., Contemporary urbanism in Brazil beyond Brasilia, University Press of Florida: Gainesville: Florida, pp. 17-30, 2009.

[2] Coelho, A., Streets alive: elements that make the city. Infohabitar: The Journal of Inhabit Group, Year VIII, Article XXVI Series inhabit and live better, No. 417, Lisbon, 2012.

[3] De Paoli, D., O valor do desenho urbano na construção de bairros habitacionais. Ph.D. Thesis (Doctor of Architecture, Technology and the City). Department of Architecture and Construction. University of Campinas. Campinas, SP, Brazil, 2014, p. 249.

[4] Santos, M. O espaço do cidadão, 5 ed., Nobel, São Paulo, 2000, p. 142.

[5] Tu, K. \& Lin, L., Evaluative structure of perceived residential environment quality in high-density and mixed-use urban settings: An exploratory study on Taipei City, Landscape and Urban Planning, No. 87, pp. 157-171, 2008.

[6] Castello, L., Redesigning Brownfields in Porto Alegre. (Chapter 8). Contemporary urbanism in Brazil beyond Brasília, ed. V. Del Rio \& W. Siembieda, University Press of Florida: Gainesville: Florida, pp. 181-197, 2009.

[7] Kostof, S., The city shaped: urban patterns and meaning through history, Thames \& Hudson, London, pp. 9-41, 2009.

[8] Lamas, J., Morfologia urbana e desenho da cidade, Fundação Calouste Gulbenkian, Lisbon, pp.19-61, 2011.

[9] Detr \& Cabe, The value of urban design. Department of the Environment, Transport and the Regions, Commission for Architecture and the Built Environment. Great Britain, 2000, p. 111.

[10] Carmona, M. et al., Public places urban spaces - The dimensions of urban design, Architectural Press, Oxford, 2003, p. 312.

[11] Fadda, G. \& Jirón, P., Calidad de Vida: una Metodología para la Investigación Urbana. Revista de la Escuela de Economía y Negocios, UNSAM, No. 1, pp. 175-187, 1999.

[12] Levi, L. \& Anderson, L. La tensión psicosocial. Población, ambiente y calidad de vida, El Manual Moderno, México, 1980, p. 149.

[13] Thomson, D. et al., Managing Value and quality in design, Building Research \& Information, 31(5), London, pp. 334-345, 2003.

[14] Granja, A. D. et al. A natureza do valor desejado na habitação social. Ambiente Construído, 9(2), Porto Alegre, pp. 87-103, 2009.

[15] Tweed, C. \& Sutherland. M., Built cultural heritage and sustainable urban development, Landscape and Urban Planning, 83(1), 2007 p. 623.

[16] Brown, G. \& Raymond, C., The relationship between place attachment and landscape values: Toward mapping place attachment, Applied Geography, 27(2), p. 897, 2007.

[17] Egan, John (coord.), The Egan Review: skills for sustainable communities. Office of the Deputy Prime Minister, London, 2004, p. 108. 
[18] Mcindoe, G R. et al., The value of urban design: the economic, environmental and social benefits of urban design. Ministry for the Environment. Wellington, New Zealand, 2005.

[19] Jenks, M. \& Jones, C., Dimensions of the sustainable city. Future city. v.2, Springer, United Kingdom, 2010, p. 288.

[20] Del Rio, V. \& Oliveira, L. (org.), Percepção ambiental: a experiência brasileira. 2 ed., Studio Nobel, São Paulo, 1999.

[21] Morikawa, T., Incorporating Stated Preference Data in Travel Demand Analysis. Ph.D. Thesis (Doctor of Philosophy). Department of Civil Engineering, Massachusetts Institute of Technology, Cambridge, 1989, p. 203.

[22] Kowaltowsk, D. \& Granja, A., The concept of desired value as a stimulus for change in social housing in Brazil, Habitat International, 35(3), 2011, p. 435.

[23] Vitória, Prefeitura Municipal de Vitória. Governo do Estado do Espírito Santo. Plano Diretor Urbano de Vitória. Documento de trabalho ${ }^{\circ} 4$. Parte continental do município de Vitória. Vitória, ES, Brazil, 1978. 